\title{
Mães presas, filhos desamparados: maternidade e relaçóes interpessoais na prisão
}

I ${ }^{1}$ Nelia Maria Portugal Flores, ${ }^{2}$ Luciane Najar Smeh I

Resumo: O objetivo deste estudo foi elucidar a repercussão da prisão da mulher no âmbito da maternidade

${ }^{1}$ Universidade Franciscana (UFN). Santa Maria-RS, Brasil (neliapflores@bol.com.br). e das relaçóes interpessoais, estabelecidas antes e durante o cumprimento da pena. Trata-se de pesquisa exploratória e transversal com delineamento qualitativo, com 15 ORCID: 0000-0002-0916-383X

${ }^{2}$ Universidade Franciscana (UFN). Santa Maria-RS, Brasil (lucianenajar@yahoo.com.br). participantes presas em regime fechado. Foram realizadas ORCID: 0000-0002-3068-3776 13 entrevistas semiestruturadas e três grupos focais entre abril e julho de 2017. Os dados obtidos foram submetidos a uma análise de conteúdo. Concluiu-se que a precariedade das relaçóes interpessoais estabelecidas durante o cumprimento da pena influencia na possibilidade do exercício da maternidade no contexto prisional. Por isso, é necessário investimento para mediar o ambiente prisional, a fim de torná-lo mais favorável às relaçóes interpessoais entre as presas, o que poderá propiciar um ambiente menos hostil para o acolhimento de visitantes, tendo em vista o fortalecimento dos vínculos com filhos e familiares.

> Palavras-chave: prisões; relação mãe-filho; relações 


\section{Introdução}

A entrada da mulher que é mãe no sistema carcerário brasileiro envolve uma mudança drástica na rotina, não só na vida dessas mulheres, mas também na da família, especialmente na organização do cotidiano dos filhos. Segundo o Levantamento Nacional de Informaçóes Penitenciárias — Infopen (BRASIL, 2017), $74 \%$ das presas têm filhos, o que significa que, na maioria dos casos de prisão, há crianças e adolescentes que são separados de suas mães.

Há alguns dados que auxiliam na compreensão do cenário prisional em relação às mulheres detentas. A população prisional feminina no Brasil, entre $2000 \mathrm{e}$ 2016, cresceu 455\%. Sabe-se grande parte das presas no país é jovem, 50\% têm menos de 29 anos e estão em fase economicamente ativa da vida. A escolaridade delas é muito baixa, sendo que $45 \%$ têm o ensino fundamental incompleto e $15 \%$ o fundamental completo. Em relação à raça, há predomínio da negra, totalizando $62 \%$ das presas (BRASIL, 2017).

A população carcerária feminina é formada por brasileiras e estrangeiras, 53\% das estrangeiras no sistema prisional vieram da América; 27\%, da África; 13\%, da Europa. Outro dado relevante para este estudo é que, das 1.420 unidades do sistema penitenciário estadual existentes no Brasil em junho de 2014, 7\% eram voltadas para as mulheres e $17 \%$ são consideradas mistas, já que podem ter uma sala ou ala específica para mulheres dentro de um estabelecimento anteriormente masculino (BRASIL, 2014).

De maneira geral, pessoas que estão privadas de liberdade têm um histórico de educação deficitária, infração juvenil, uso de drogas e envolvimento com o tráfico (BARCINSKI; CUNICO, 2014). No que se refere às mulheres, destacam-se as histórias prévias de violência, abandono e associação ao delito em decorrência dos relacionamentos com homens criminosos (HUANG; ATLAS; PARVEZ, 2012). Para Cerneka (2009), a pobreza e a dependência química são os fatores mais agregados ao engajamento das mulheres em atividades criminosas.

Estar preso influencia a condição humana porque isso produz várias rupturas com o meio social e familiar, uma vez que a prisão determina o afastamento da família, filhos, parceiros, amigos e do ambiente social (LIMA et. al., 2013). Apesar disso, o número de estudos brasileiros com mãe presidiária tem apresentado um crescimento 
lento e gradativo. No Brasil, as publicaçóes recentes que versam sobre as mulheres que gestam e ganham seus filhos durante o cumprimento da pena em regime fechado destacam-se por revelar o panorama nacional quanto à saúde materno-infantil no contexto prisional (FOCHI et al., 2017; LEAL et al., 2016; SILVA, 2015).

No entanto, há carência em relação às publicações de pesquisa no país sobre a repercussão da prisão materna para criança/adolescente, que é um tema mais explorado em estudos internacionais (ARDITTI, 2012; POEHLMANN; SCHLAFER; MAES, 2008; RAEDER, 2012). Por isso, neste estudo, o intuito é acrescentar informaçóes ao discutir, a partir do relato de mães presas, vivências na relação mãe-filho(a) que são perpassadas por relações interpessoais, inclusive as estabelecidas dentro do presídio, que também reverberam na experiência de maternidade das presas. Trata-se de dar visibilidade a uma realidade invisível para a sociedade, o governo e as políticas públicas e, ao mesmo tempo, convidar os leitores a uma reflexão em torno dos avanços possíveis em benefício da saúde mental da díade mãe presa e seus filho(a)s. Teve-se por objetivo elucidar a repercussão da prisão da mulher no âmbito da maternidade e das relaçóes interpessoais, estabelecidas antes e durante o cumprimento da pena.

\section{Método}

Trata-se de pesquisa exploratória e transversal com delineamento qualitativo, realizada no presídio regional de uma cidade no interior do Estado do Rio Grande do Sul, no período entre abril a julho de 2017. ${ }^{1}$ Nos meses de coleta de dados para este estudo, o número total de presas no local variou de 66 a 75 mulheres. As participantes da pesquisa foram 15 que se encontravam presas em regime fechado. Levaram-se em conta no estudo, como critério de inclusão, mães que no período da coleta de dados tinham um ou mais filhos na fase da infância/adolescência.

A faixa etária delas variou entre 20 e 57 anos; na escolaridade, predominaram as que tinham o ensino fundamental incompleto e apenas uma se declarou analfabeta. Para melhor caracterizar as participantes, os dados da entrevista sociodemográfica foram organizados em uma tabela. 
Tabela 1. Caracterização das mães participantes

\begin{tabular}{|c|c|c|c|c|c|}
\hline Máe & Idade & Escolaridade & Profissão & $\begin{array}{l}\text { Número } \\
\text { de filhos }\end{array}$ & $\begin{array}{l}\text { Recebe visita } \\
\text { dos filhos }\end{array}$ \\
\hline M1 & 37 & $7^{\circ}$ ano ens. fundamental & Do lar & 4 & Não \\
\hline M2 & 26 & Ensino médio completo & Pizzaiola & 1 & $\operatorname{Sim}$ \\
\hline M3 & 34 & $\begin{array}{l}\text { Ensino fundamental } \\
\text { completo }\end{array}$ & Empresaria & 2 & Sim \\
\hline M4 & 29 & $6^{\circ}$ ano ens. fundamental & Recicladora & 3 & Náo \\
\hline M5 & 49 & Analfabeta & Do lar & 10 & Náo \\
\hline M6 & 27 & Ensino médio completo & Não informada & 9 & Não \\
\hline M7 & 20 & $1^{\circ}$ ano ensino médio & Não informada & 1 & Sim \\
\hline M8 & 23 & $\begin{array}{l}\text { Ens. fundamental } \\
\text { completo }\end{array}$ & $\begin{array}{l}\text { Auxiliar de } \\
\text { cozinha }\end{array}$ & 2 & Não \\
\hline M9 & 57 & $3^{\circ}$ ano ens. fundamental & Cozinheira & 5 & Não \\
\hline M10 & 35 & Ensino médio completo & Cozinheira & 2 & Sim \\
\hline M11 & 36 & Ensino médio completo & $\begin{array}{l}\text { Empregada } \\
\text { doméstica }\end{array}$ & 2 & Náo \\
\hline M12 & 31 & $7^{o}$ ano ens. fundamental & Faxineira & 4 & Não \\
\hline M13 & 42 & $4^{\circ}$ ano ens. fundamental & $\begin{array}{l}\text { Atendente de } \\
\text { padaria }\end{array}$ & 3 & Náo \\
\hline M14 & 27 & $\begin{array}{l}\text { Ens. fundamental } \\
\text { completo }\end{array}$ & $\begin{array}{l}\text { Empregada } \\
\text { doméstica }\end{array}$ & 4 & Sim \\
\hline M15 & 32 & $\begin{array}{l}\text { Ens. fundamental } \\
\text { completo }\end{array}$ & $\begin{array}{l}\text { Auxiliar de } \\
\text { faxina }\end{array}$ & 3 & Não \\
\hline
\end{tabular}

Os dados foram coletados por meio de 13 entrevistas semiestruturadas individuais e três grupos focais. Este é um tipo de entrevista que, segundo Flick (2009), permite a participação de todos os componentes e produz um conteúdo rico em relaçáo ao tema proposto. Os encontros dos grupos focais aconteceram em uma sala de atendimento dentro do presídio, com a mediação da pesquisadora e apoio de uma auxiliar de pesquisa para gravaçóes do áudio, as quais foram transcritas 
posteriormente. No primeiro grupo, participaram seis mães; no segundo, três; e, no terceiro, três. Como disparador do grupo focal, foi solicitado às participantes que falassem sobre a experiência da maternidade na vida delas. Houve a participação ativa de todas as componentes por meio de seu relato pessoal, diálogos e troca de ideias. Cada encontro de grupo teve duração média de $1 \mathrm{~h} 30 \mathrm{~min}$.

As presas participantes foram indicadas pela psicóloga e pela assistente social do presídio. $\mathrm{O}$ critério de escolha, segundo o informado às pesquisadoras, foi a disponibilidade da presa para participar das atividades propostas no presídio, além da vontade de falar sobre o tema. No total, participaram 15 mulheres, sendo que a maioria (dez) participou do grupo focal e da entrevista individual; três participaram somente da entrevista e, consequentemente, duas participaram apenas do grupo focal. Após indicação dos nomes de prováveis participantes, o convite inicial às presas foi feito pela psicóloga do local. As que demonstraram interesse em participar passavam para uma sala, na qual a pesquisadora explicava o estudo e as questôes éticas. Apenas uma das presas convidadas náo aceitou participar.

Os dados relacionados às entrevistas semiestruturadas e ao grupo focal foram gravados em áudio e, posteriormente, transcritos naíntegra. Depois, foram submetidos à técnica de análise de conteúdo proposta por Bardin (2011). Conforme requer a técnica, em uma primeira etapa foi realizada uma leitura flutuante, que consistiu na leitura inicial das falas, buscando a identificação dos principais significados que os participantes do estudo atribuíram ao assunto investigado nas entrevistas. Assim, na fase da exploração dos materiais, o conteúdo colhido foi listado e, posteriormente, agrupado, conforme similaridade dos temas, resultando nas categorias finais. Ao término da análise, surgiram seis categorias. Neste artigo serão elucidadas e discutidas duas grandes categorias. São elas: "Maternidade fraturada: uma via de mão dupla" e "Mães presas: o abandono afetivo e as relaçóes interpessoais na prisão".

Para cumprir os critérios éticos desta pesquisa, foram atendidas às recomendaçôes da Resolução n 466/2012 do Conselho Nacional de Saúde, que prescreve a ética em pesquisa com seres humanos (BRASIL, 2012). O projeto foi submetido e aprovado pelo Comitê de Ética em Pesquisa do Centro Universitário Franciscano, conforme Parecer no 2346474 de 2017. Para manter o sigilo quanto à identidade das participantes, as falas foram denominadas, no texto, pela letra " $\mathrm{M}$ ", inicial da palavra mãe, seguida de um número arábico. 


\section{Resultados e Discussão}

\section{Maternidade fraturada: uma via de máo dupla}

$\mathrm{O}$ impacto nocivo da pena de privação de liberdade não age apenas sobre a presa, mas também, e de forma ainda mais grave e injusta, sobre sua família. Todo o sistema familiar é afetado em relaçáo ao declínio da situação financeira, rompimento das relaçôes de amizade e de vizinhança, enfraquecimento dos vínculos afetivos, problemas na escolaridade dos filhos e perturbaçóes psicológicas decorrentes da percepção de exclusão social (WACQUANT, 2004).

Ao tratar da separação mãe/filho em razão do cárcere, Stella (2009) traz à tona questôes como a culpabilização sobre o abandono, abalos na estrutura familiar e a possibilidade de o filho desamparado "retroalimentar a carreira do crime". Conforme a autora, a prisão amplia a crença social de que a conduta ilícita dos pais possa vir a ser transmitida para os filhos e, em consequência, essa crença pode permear as relaçôes estabelecidas pelos filhos, dificultando assim o processo de socialização e individuação. Neste estudo, foi possível constatar que há nas mães também um receio de que seus filhos, especialmente os adolescentes, cometam delitos e acabem presos.

Há situaçôes em que os filhos de mulheres que cumprem pena são cuidados por parentes distantes, amigos da mãe ou em uma casa de acolhimento. Nesta pesquisa, duas participantes relataram também a prisão das mães e irmãs no mesmo momento em que ocorreu a sua prisão. Assim, em alguns casos, os membros da família mais próximos também ficarão encarcerados e isso revela que a criança perde mais de uma referência afetiva; ela fica sem a mãe, avó, tias. A mãe M12 conta sobre a situação dos filhos no momento em que ela e sua mãe, avó das crianças, foram presas:

Primeiro, eles ficaram com a minha irmá. Depois, com a minha irmá, porque ela tinha os dela né, daí tava aquela função, os meus, tipo, os meus pequenos brigavam com os pequenos dela, e a minha guria foi pra casa de uma amiga minha. Daí lá também não deu certo, ela foi pra casa de uma comadre minha. Daí por último, ela ficou com a mulher do meu irmão, que foi até que a mãe saiu daí. E depois, a minha sogra queria ficar só com os guris, com as gurias não, daí não dá né, como é que eu ia separar eles? (M12).

Em relação aos cuidadores que substituem a mãe, no estudo de Poehlmann, Schlafer e Maes (2008), entrevistaram-se 92 presas e constatou-se que a maioria estava preocupada com a qualidade/estabilidade dos cuidados. Além disso, as crianças eram mais propensas a se adaptar quando os cuidadores eram contínuos e escolhidos pela mãe; quando o cuidador era o pai e quando a relação mãe-cuidador 
era positiva. Esse resultado indica a importância de quem assume o lugar materno, tanto para o bem-estar da presa quanto para o desenvolvimento da criança, inclusive porque é essa pessoa que vai narrar para criança a história materna.

Mas o que dizer às crianças quando elas perguntam sobre a sua mãe? Entre as participantes deste estudo, algumas optaram por dizer a verdade sobre a situação prisional, já outras optam por alimentar a fantasia na criança de que a mãe está trabalhando em outra cidade ou argumento semelhante. Segundo Valente; Hadler; Costa, (2012), por não receberem a informação real sobre o paradeiro da mãe, muitas crianças vivenciam o abandono tanto quanto as mulheres presas. Algumas entrevistadas não tiveram escolha, perderam o lugar de decisão sobre a criança e, por isso, precisam lidar com o que os cuidadores contam para a criança.

Mas assim, ninguém fala pra ele: “a tua mãe tá presa”, até mesmo porque uma criança de quatro anos não sabe, né, o que que é tá presa, né? (M3).

A situação de privação de liberdade pode ser omitida para os filhos, pois familiares, muitas vezes, não revelam a verdade, optando por imprimir nos filhos das presas palavras de alienação parental ou simular a morte delas (SPINDOLA, 2016). A ruptura na convivência com a mãe em função da prisão é diferente de uma separação por morte ou divórcio. Isso porque, no caso de cumprimento de pena, há uma mudança do papel social da mãe e a repercussão do significado do presídio na sociedade (STELLA, 2009).

Segundo a pesquisa de Diuana, Correa e Ventura (2017), a prisão representava para as mulheres encarceradas uma violência que se exercia sobre elas e seus filhos, gerando angústia, ansiedade, depressão e revolta. Para elas, o sentimento preponderante era de que a pena se estendia a seus filhos, e eles não mereciam isso.

A angústia de náo poder acompanhar e intervir no desenvolvimento dos seus filhos é um dos pesares expressos pelas presas. A situação é ainda mais complexa porque é comum que as crianças sejam destinadas aos cuidados de responsáveis que já possuem outros menores sob sua guarda. Logo, por vezes, os cuidados e orientaçôes recebidos por elas não vão ao encontro do desejo de suas mães (ORMEÑO; MAIA; WILLIAMS, 2013).

As mães M1 e M3 mencionaram preocupação com a adaptação da criança em relação às novas regras, disciplina e organização da vida doméstica imposta pelo cuidador(a) que fica responsável pelos filhos da presa. Os adolescentes sofrem porque 
compreendem melhor a realidade da situação da mãe. Além disso, as mudanças próprias da idade e conflitos da fase podem dificultar a relação interpessoal estabelecida com o cuidador(a). Conforme as participantes deste estudo, a responsabilidade pelos menores é assumida, com mais frequência, não só por avós e tias, mas também foram citados amigas, vizinhas, pai ou padrasto. No caso de M3, o filho adolescente está com o pai e ela revela sua preocupação:

Eu, eu criei ele acho que, como toda mãe cria, sei lá se dei muito, muita regalia, mas né, sei lá, foi... Eu achava certo o modo que eu tava criando ele, tinha internet, tinha telefone, tinha o que um guri da idade dele quer, né? E o pai dele não dá nada disso, nada pode, nada dá, sabe? É, então assim ó, o guri foi criado de um jeito e do nada cortaram tudo dele. Aí que ele ficou rebeldezinho, não queria estudar (M3).

A minha guria de 12 anos, agora ela começou a me dar um pouco de trabalho né, com as amizades, essa função de a gente não tá lá, eu não tá lá né, daí tá só a minha mãe, e a minha mãe fala que ela respeita, é que ela é bem quieta, na dela, sabe? E ela, tipo, ano passado, ela rodou, ela ficou um mês sem ir na aula, daí não tinha, tava naquela função de ter alguém pra ficar com eles, daí eles ficaram rodando de casa em casa. Daí ela ficou um mês sem ir na aula por causa da pequena, porque a pequena náo ficava longe dela, daí ela rodou (M12).

É, eu convivia com as gurias né, e a guria pequena que não deu pra conviver, ela nasceu, tava com três meses quando eu vim. Agora ela tá com o pai dela em Viamão. Eu queria ver se não conseguia um projeto pra colocar o menino, sabe, pra ele não se perder, não vou mentir, começou a fumar maconha, eu não queria isso pra ele, e a tia dele, minha irmã, segura às vezes, só que eu sei que ele é bom aluno, são boa as notas dele, queria ver se conseguia aqui um projeto pra colocar ele, sabe... (M1).

No relato de M1 são expressos o sentimento de impotência e as limitaçóes da condição das presas para o exercício da maternidade, pois elas compreendem que a adolescência é um período importante no encaminhamento da vida para a fase adulta. Gostariam de poder intervir, mas estão impossibilitadas. Logo, a angústia está na possibilidade de o(a) filho(a) repetir sua própria história e acabar na prisão.

Eu precisava de uma renda assim pra ajudá ele, pra ele entrá num jovem aprendiz ou alguma coisa pra ele pode comprá as coisa dele e não fica revoltado pela rua, na maconha. Ele já andava desse jeito e eu não quero isso pra ele, Deus o livre, e ele disse "mãe, eu quero que tu me ajuda”, mas ele pede pra mim ajuda, mas eu não tenho como fazer nada (M1).

Eu queria tá com eles, eu queria pode dá a educação pra eles que eu penso eu tô tentando trabalhá, fazer tudo que eu posso pra pode ir o mais rápido possível, porque eu sei que eles táo precisando de mim agora no momento, principalmente, o adolescente tá mais necessitado, que é a hora que eu tenho que tá mais do lado dele é agora e agora eu tô aqui né, mas eu vô embora ano que vem (M11). 
A fala da participante M11 indica que o desejo de retomar o exercício da maternidade a motiva para o trabalho e o bom comportamento na instituição prisional. Voltar ao convívio com os filhos é o principal objetivo a ser alcançado, e isso as torna mais capazes de enfrentar as adversidades vividas no presídio. No estudo de Lima et. al. (2013), afirma-se que os filhos são um dos fatores que contribuem para a resiliência diante do confinamento da mulher.

Ao falar sobre a maternidade, as participantes ressaltaram a preocupação com a educação escolar dos filhos, pois elas costumam receber informações de fora sobre o desempenho deles na escola. No estudo de Soares, Cenci e Oliveira (2016), ficou evidenciado que apreensão por uma escolaridade de qualidade para os filhos está vinculada ao receio de que eles possam vir a repetir os comportamentos infratores de suas mães, pois elas desejam que os filhos construam um caminho diferente e melhor.

Após a separação mãe-filho no momento da prisão, a criança experimenta um processo de luto e precisa elaborar a situaçáo familiar real. Os reflexos dessa experiência dolorosa podem vir a se manifestar no processo de aprendizagem da criança que, em decorrência dos seus conflitos internos, passa a apresentar dificuldades no âmbito escolar.

[...] ele é gago, ele regrediu bastante depois que eu vim porque ele tá na terceira série e não sabe lê ainda, as professoras tão passando e eu me preocupo com ele [...] (M1).

Logo que eu cheguei aqui né, terminou o colégio lá, e deu a decisão de quem tinha passado ou rodado, que ela tinha rodado pela frequência e não por ela não ter feito os trabalhos e coisa. Porque ela é uma aluna ótima, mas sim por causa da frequência, porque as notas tavam boas, a diretora falou, que ela entendia né, que ela tava passando por uma situação... (M3).

Conforme os relatos das participantes, a prisão delas tem implicaçôes de significados sociais que se sobrepóem à escolarização dos filhos, reforçando os prejuízos que o afastamento da mãe representa na vida deles (STELLA, 2009). Geralmente, ainda que, na atualidade, essa realidade esteja se modificando, a inserção e o acompanhamento da vida escolar dos filhos são responsabilidades atribuídas à mãe. Com a privação de liberdade, ela fica impossibilitada de acompanhar o processo educativo das crianças (FREIRE, 2017).

Pesquisa realizada por Poehlmann (2005) concluiu que 63\% das crianças filhas de presas apresentam relacionamentos inseguros com suas mães e cuidadores. No entanto, quanto mais segura for a relação da criança com seus cuidadores, maior a 
probabilidade de ela reagir à separação da mãe com tristeza, e não com raiva. Os resultados do estudo também revelaram que, diante da separação de suas mães, as crianças costumam apresentar tristeza, preocupação, confusão, raiva, solidão, medo, problemas de sono e retrocesso no desenvolvimento.

Nos Estados Unidos, de acordo com Poehlmann et. al. (2010), em torno de 1,7 milhão de crianças têm pais que estão na prisão. Por isso, essas crianças apresentam um risco maior de desenvolver problemas de comportamento, evasão escolar e abuso de substâncias. Também por isso, acredita-se que o bom vínculo e a convivência com a mãe nas visitas poderiam ter um efeito preventivo no desenvolvimento da criança. No entanto, neste estudo, algumas mães justificaram sua preferência por não receber a visita dos filhos. Elas temem que eles sejam expostos a um ambiente de relaçôes interpessoais permeadas por hostilidade, nas quais não há reciprocidade de apoio e acolhimento. Logo, solicitar a visita e ver os filhos dentro do ambiente prisional seria infligir mais sofrimento a elas e seus filhos.

\section{Máes presas: o abandono afetivo e as relaçóes interpessoais na prisão}

Fragilizadas pela separação dos filhos, as mulheres ainda precisam lidar com os estressores presentes nas condiçôes de vida da prisão. Isso porque eles podem contribuir em grande parte para o comprometimento da saúde mental das presas. Riscos de adoecimento mental, como depressão, e até suicídio estão presentes na população apenada (LIMA, 2013). Somado à quebra de vínculos das relaçôes anteriores devido ao cumprimento da pena, há uma atmosfera hostil nas relaçóes entre as presas. A sobrecarga de fatores negativos torna as relaçôes frágeis neste ambiente e contribui, significativamente, para um clima de desconfiança, seja com as companheiras de detenção, com a própria família, seja até mesmo com a equipe profissional que compóe o cárcere. As relaçôes são superficiais e pouco confiáveis no grupo de presas. Isso parece alimentar a insegurança e a solidão na vida das participantes, o que é ilustrado por meio dos relatos dessas neste estudo:

[...] elas não gostam de te vê bem, ninguém gosta de vê ninguém bem lá dentro, então ali dentro tudo que é negativo tem ali dentro, entendeu? Não tem nada positivo ali (M14).

[...] ali dentro assim, são duas ou três que se gostam assim, na moral, nem as famílias que moram tudo junto ali se gostam... Eu penso assim, se tu vai, atrai uma coisa ruim pro teu lado, tudo bem, mas náo vem, atrai pro lado dos outros, tu entende? (M5). 
Entâo o melhor jeito de tu conviver dentro de uma cadeia é tu ficar com menos pessoas, menos quantidades, porque é dividido em grupos, tem uma que a gente se dá mais, tem umas que a gente se dá menos[...], então é melhor tu não se dar com muitas, falar pouco, ouvir muito. Ver quase nada (M8).

Lá se te deixarem um vidro de shampoo, qualquer coisa em cima, ahn...Tu coloca na tua mesinha, não tem mais, tu vira o corpo, só vira o rosto assim, e te roubam (M4).

Os relatos ratificam ao que se refere Lima (2013) sobre o ambiente carcerário se caracterizar como um local que náo propicia o suprimento da necessidade de relacionamento, pois a atmosfera gira em torno de fatores como opressão, desconfiança e temor, o que dificulta a possibilidade dessas mulheres viverem com mais saúde mental. Varella (2017) ressalta que a imposição de normas e as relaçôes de mando, tão lineares entre homens presos, adquirem complexidade incomparável no caso das mulheres, porque as emoçôes entram em jogo com o mesmo peso da racionalidade.

De 60 e poucas mulher tu tira 5. Que te ajudam assim, não por interesse de alguma coisa, tu entendeu? (M1).

Aqui é horrível cara, não tem noção. Dá muita fofoca. Aqui as amizades são compradas, o que tu tiver, tu vale o que tu tem. Se tu tem um tênis melhor, uma sacolinha maior, aí tu vale alguma coisa, se tu não tem nada, se tu não faz nada, daí tu não presta. (M8).

Tu se incomoda, te roubam, então, né...? O pouco que tu tem te roubam, então é complicado... (M3).

Tem uma base de umas 50 né...? Umas 39, 40 mulheres tem agora...É muita... É muita loucura muita ladainha... muita discussão, briguinha, tipo assim, tem umas que arrumam qualquer coisa para se encarnar nas pessoas, tipo eles não gostam ninguém lá dentro, gostam de vê uma pessoa bem (M5).

Já teve briga com agressão física... Credo pulou eu acho umas seis em cima de mim sim, machucaram meu rosto me pegaram sentada fizeram horrores comigo (M6).

As difíceis relaçooes entre as presas, a falta de acolhimento, a dificuldade de confiar, confidenciar e conviver é uma realidade na vida grupal da cadeia. Um ambiente tenso, conflituoso e marcado por brigas e discussôes, realidade que também contribui para as poucas visitas de crianças às suas mães. Considerando que o estabelecimento prisional no qual foi realizado este estudo é uma instituição penal mista, isto é, foi construído para abrigar homens e, posteriormente, teve que ser adaptado para mulheres. Ele dispóe de uma infraestrutura física precária e, por isso, as visitas são coletivas, nas quais todas as presas recebem seus filhos no pátio. 
Entre as participantes deste estudo, apenas cinco já receberam pelo menos uma visita dos filhos.

A visita deles é muito pouca né, poucas vezes... Eu nem vejo, se não é esse passeio, eu nem tinha visto eles (M12).

É uma função né, porque no inverno é muito frio e tem que ficar no pátio, vieram os de quatro anos, não para, dá última vez que ele veio tava chovendo, foi uma briga porque ele ficava em baixo ali da coisa, pra não se molhar tudo. E no verão é um forno de quente também aquilo ali né, mas eles vêm a cada três meses (M3).

[...] É... é difícil pra eles, eu sei que eu errei, eu tô pagando pelo que eu fiz e não quero que os meus filhos venham ver também (M9).

Aí é com sentimento de saudade, de falta, porque a gente... Eu não tenho visita delas, elas não vêm, e eu também não quero que elas venham porque aqui não é um lugar pra elas (M8).

Diante de um ambiente hostil, da falta de afeto, da ausência dos filhos, relacionamentos homossexuais são frequentes e podem ser compreendidos como uma forma de lidar com a solidáo, com a carência provocada pelo abandono e pela falta de relaçóes sociais mais abrangentes. Segundo Varella (2017), as práticas homossexuais na cadeia envolvem a maioria das presas. $\mathrm{Na}$ experiência como médico de um presídio, o autor salienta que as presas não são forçadas a manter relaçôes amorosas náo consentidas, mas quando a química acontece, as parceiras solicitam mudança de cela para morar juntas. A restriçáo do espaço físico, o confinamento com pessoas do mesmo sexo, a falta de carinho, ausência masculina e o abandono afetivo formam as condiçóes socioambientais para que a mulher realize seus desejos íntimos, reprimidos na vida em sociedade.

É fato que as mulheres privadas de liberdade utilizam estratégias de resistência e visibilização no cárcere. Entre as estratégias estão a maquiagem e a forma de arrumar o cabelo, porque minimizam a despersonalização e uniformização promovidas pela instituição prisional (CUNHA, 1994, 1996). Outro aspecto para a compreensão do fenômeno são as relações interpessoais estabelecidas dentro da prisão: elas podem ser entendidas como relaçóes afetivas de pai, mãe e filha que se reeditam entre as mulheres presas (BARCINSKI, 2012). Assim, a partir dos relatos coletados neste estudo, pode-se pensar que as relações homossexuais também são uma alternativa para minimizar a despersonalização.

Sobre estratégias de visibilização adotadas em unidades prisionais femininas, Barcinski (2012), em pesquisa realizada com presas que se vestiam e se portavam 
como homens na prisão, identificou que a incorporação de trejeitos masculinos lhes garantia poder e acesso aos privilégios socialmente atribuídos aos homens, tais como o exercício legitimado da força e da poligamia. Neste estudo, três das participantes relataram o seu envolvimento afetivo e sexual com outras presas:

É... eu, quando eu vim presa em 2011 eu conheci ela, e aí a gente começou a conversar e acabou se envolvendo e... fiz liga, fiz união estável (M2).

Em alguns casos, como relata M3, a união homossexual na cadeia é mais um agravante nas relaçôes familiares que já são abaladas pela prisão. A família passa a ter que lidar com mais uma adversidade, o que pode desencadear redução de visitas e mais abandono afetivo por parte da família.

O meu pai no dia que ele ficou sabendo, que a minha irmá contou pra ele, ele disse que ele preferia me ver morta do que do lado de uma mulher. Tá, né. Se é uma, uma decisão dele, vamo dá um tempo pra cabeça dele, né? (M3).

Nesse viés, a necessidade de sobreviver à prisão e alimentar esperanças para o futuro promove rupturas e tentativas de recomeços, talvez formas de dar um novo sentido para a vida, durante um tempo que passa lentamente. No caso da participante M11, o envolvimento com outra presa gerou a finalizaçáo de um casamento de dez anos.

Ele ainda não aceita a separação, ele ainda, ele ainda... Ele tá tendo a vida dele, mas ele sempre tem esperança, não dexô de tê esperança, mas eu não.... Eu não sei o dia de amanhã mas por enquanto eu não volto atrás porque eu até tenho outro relacionamento agora [...] os meus filhos já estão a par do meu relacionamento, já conhecem a pessoa tudo. É uma coisa que deixou eles muito confuso porque o meu relacionamento é com uma menina [...] eu já estava aqui, a gente se conheceu por aqui (M11).

M11 se refere à repercussão do relacionamento para os filhos, fato que lhes exige ainda mais e os desafia em relação à imagem da mãe, considerando que até o momento da prisão, a mãe mantinha um relacionamento heterossexual estável. Sem dúvida, a vida afetiva da mãe, ainda que dentro da instituição prisional, reverbera na vida dos filhos e demais familiares.

Além do abandono afetivo, proveniente da perda de convivência com maridos/ companheiros/namorados, familiares, amigos e filhos, as relaçóes entre as presas não contribuem para acalentar o sofrimento; pelo contrário, intensificam o sentimento de solidão. De acordo com Varella (2017), a falta de afeto gera sentimentos diversos, que variam da solidão ao desespero. As presas recebem pouca ou nenhuma atenção, e essas mulheres acabam esquecidas pelos familiares e até pelo próprio Estado. 
Múltiplos fatores são responsáveis pelo abandono que se apresenta na forma de ausência de visitas. Há que se considerar o custo de deslocamento para as famílias, pois, algumas vezes, a instituiçâo prisional não é na mesma cidade em que reside a família. Por isso, ao longo dos anos, os laços podem se enfraquecer, e a visita pouco frequente se transforma em nenhuma visita. Além disso, as mulheres da família geralmente assumem os cuidados dos filhos da presa, dificultando a possibilidade de esses se afastarem para visitas. Há também os casos em que a família não consegue perdoar o ato criminoso cometido pela mulher, conforme relata a M1 sobre a relação com a sua mãe:

Ela me chamava de assassina, de um monte de coisa, então a gente só se dá bem assim de "oi tudo bom, mãe beijo e eu já tô indo porque eu tenho que i embora" e ela também sai da onde eu tô (M1).

A mulher presa sofre o preconceito por ser mulher e ter cometido um crime e, geralmente, há uma condenação da própria sociedade em relação à mulher que é mãe e cumpre pena de restrição de liberdade. O sofrimento da família e, em decorrência a rejeição, infringe uma dor extrema, que é expressa nas palavras das participantes:

[...] eu sô a ovelha negra e os meus irmáos que ela ama, ela ama eles, eu sempre foi diferente, a gente nunca ficô nem dois dias junto né, era um dia de bem e eu tinha que i embora... (M1).

Entâo é a discriminação, o preconceito, vem de ambas as partes. Tanto do lado da família, quanto do lado dos amigos e de alguém que conheceu a gente de uma forma e já presenciou de outra, é bem complicado. Meu próprio pai no caso não tem só eu no sistema prisional, tem dois irmãos, um tá em $\mathrm{MG}$, outro tá aqui na cadeia masculina, só que ele (pai) nun, pra ele, nós somos as ovelhas negras, nunca ele botou os pés aqui, nunca ele quis saber se tava tudo bem, se precisava de alguma coisa (M8).

Irmãos, tenho, mas só que os meus irmãos assim como eu tive esse erro na minha família eles não, eles não aceitam esse tipo de coisa, então eu fiquei totalmente excluída, né? Nós fomos criados no sistema antigo, né, é trabalhá pra vivê, pra adquiri as coisa trabalhando, como isso aí que eu tô agora na cadeia é vergonhoso pra eles (M9).

Ah, meus pais ficaram loucos, coitadinhos né por causa que são pessoas que nunca tiveram problema com nada dessas coisas... São duas pessoas de fora né, que se criaram pra fora, trabalhando pra fora... Eles ficaram apavorados e tão até hoje (M13).

De todos os tormentos do tempo de cumprimento de pena, o abandono é o que mais aflige as detentas. Elas geralmente são esquecidas pelos familiares, amigos, maridos, namorados e até pelos filhos. "A sociedade é capaz de encarar com alguma complacência a prisão de um parente homem, mas a de mulher envergonha a 
família inteira” (VARELLA, 2017, p. 38). A experiência intramuros produz danos distintos, entre eles, está o rompimento de vínculos, a deterioração da identidade feminina e uma experiência de violências sofridas, presenciadas e praticadas (SOARES; ILGENFRITZ, 2002).

As dificuldades nas relações com a família, conforme relato das participantes, são anteriores à prisão. Em geral, essas relaçóes já estão fragilizadas quando elas iniciam a pena, o que pode contribuir para um distanciamento ainda maior nos casos e, em consequência, há o abandono. Em muitos casos, ele ratifica a fragilidade dos laços afetivos. Conforme Lima (2013), o abandono dos familiares e amigos e, sobretudo, a separação dos filhos, as experiências de sofrimento são recorrentes e expressas por sentimento de tristeza, dor, desesperança e solidão. Segundo Varella (2017) e Lima et. al. (2013), isolar a presa na cadeia por anos consecutivos também pode ocasionar distúrbios de comportamento, transtornos psiquiátricos e dificultar sua capacidade de retomar a vida em sociedade.

Em outro aspecto, nenhuma das participantes entrevistadas recebia visita íntima. Tal fato ocorre porque alguns parceiros estão presos, outros justificam que estão cuidando dos filhos e não podem comparecer às visitas. Por isso, não é incomum a relação afetiva se dissolver ao longo da pena. $\mathrm{O}$ tempo livre na prisão favorece a reflexão sobre a relação amorosa estabelecida e, em alguns casos, o início da vida delas no crime aconteceu pela ação do companheiro e elas acabaram envolvidas. A participante M15 narra que acabou seu casamento porque entendeu que, se continuasse com o marido, retornaria para cumprir uma nova pena. Assim, ela optou por abrir mão da visita dele para não ficar em dívida com ele e ter que seguir casada. Assim, constata-se que as dificuldades nas relaçóes interpessoais promovem o sentimento de solidão e abandono afetivo.

\section{Consideraçóes finais}

Ao discorrer sobre maternidade e relaçóes interpessoais na vida de mulheres presas, constatou-se que ambas estáo correlacionadas. A possibilidade de maternar esbarra na precariedade das relaçôes estabelecidas durante o cumprimento da pena. A realidade neste contexto não é fácil: são mulheres carentes e fragilizadas, desprovidas de poder, voz e autoestima para exercer a parentalidade. Elas consideram o ambiente em que vivem degradante e, por isso, na maioria dos casos deste estudo, escolhem 
mantê-los distantes, ainda que sintam saudades e expressem preocupaçôes com os filhos. Então, a culpa e a vergonha pelo delito preponderam, inviabilizando o estreitamento dos laços afetivos com os filhos.

É imprescindível que a situação desses filhos mereça mais atenção da sociedade. Logo, é necessário fomentar discussôes e novas políticas públicas com o intuito de minimizar os efeitos iatrogênicos da prisão materna na vida dos filhos, geralmente crianças e adolescentes membros de famílias, nas quais a mãe é a principal cuidadora e provedora. Famílias que, sem a presença da mãe, ficam acéfalas e disfuncionais, isto é, não conseguem atender à função familiar que se refere ao cuidado e proteção das crianças e dos adolescentes. Isso também acontece porque nem sempre o(a) cuidador(a) responsável que substitui a mãe é uma pessoa que estabelece laços afetivos positivos com a criança/adolescentes.

Diante do exposto, propóem-se mais investimentos para melhorar o ambiente prisional, tanto no que se refere às relaçôes interpessoais intramuros como no espaço físico, no qual as presas recebem seus filhos. Assim, haverá condiçôes mais favoráveis que poderão estimular a presença das crianças/adolescentes nos dias de visita e, consequentemente, contribuir para o fortalecimento do vínculo máe-filho(a). Acredita-se que esse vínculo é um subsídio valioso para minimizar a repercussão negativa da prisão na vida afetiva, educacional e social dos filhos, assim como poderá ser um fator preditivo para reorganização do sistema familiar após o cumprimento da pena.

Portanto, sugere-se que novos estudos longitudinais vislumbrem avaliar os benefícios de investimentos na relação mãe-filho(a) no contexto prisional, além de buscar identificar o papel do(a) cuidador(a) responsável diante da relação máe presa-filhos. Assim, pesquisadores e as experiências narradas por mulheres presas acrescentarão conhecimentos primordiais para a fundamentação das discussões públicas sobre o tema no Brasil. ${ }^{2}$

\section{Referências}

ARDITTI, J. A. Child trauma within the context of parental incarceration: a family process perspective. Family Relations, v. 4, n.3, p. 181-219, 2012.

BARCINSKI, M. Expressões da homossexualidade feminina no encarceramento: o significado de se "transformar em homem" na prisão. Psico-USF, v. 17, n. 3, p. 437-446, 2012. 
BARCINSKI, M.; CUNICO, S.D. Os efeitos (in)visibilizadores do cárcere: as contradições do sistema prisional. Psicologia, Lisboa, v. 28, n. 2, p. 63-70, dez. 2014.

BARDIN, L. Análise de conteúdo. Trad. Luís Antero Reto e Augusto Pinheiro. Lisboa: Edições 70, 2011.

BRASIL. Conselho Nacional de Justiça. Levantamento Nacional de Informaçóes Penitenciárias - INFOPEN MULHERES - jun., 2014. Disponível em: <http://www.justica.gov.br/noticias/ estudo-traca-perfil-da-populacao-penitenciaria-feminina-no-brasil/relatorio-infopen-mulheres. pdf>. Acesso em: 10 set. 2017.

BRASIL. Conselho Nacional de Justiça. Levantamento Nacional de Informaçóes Penitenciárias - INFOPEN MULHERES. 2 edição, 2017. Disponível em: http://depen.gov.br/DEPEN/ depen/sisdepen/infopen-mulheres/infopenmulheres_arte_07-03-18.pdf/view >. Acesso em 13 agosto de 2018.

BRASIL. Ministério da Saúde. Conselho Nacional de Saúde. Resolução nº 466, de 2012. Trata de pesquisas em seres humanos e atualiza a resolução 196. Brasília, DF, 2012. Disponível em: <http://conselho.saude.gov.br/ultimas_noticias/2013/06_jun_14_publicada_resolucao.html>. Acesso em: 10 set. 2017.

CERNEKA, H. A. Homens que menstruam: consideraçôes acerca do sistema prisional às especificidades da mulher. Veredas do Direito, v. 6, n. 11, p. 61-78, 2009.

CUNHA, M. I. P. Malhas que a reclusão tece. Questôes de identidade numa prisão feminina. Lisboa: Gabinete de Estudos Jurídico-Sociais, 1994.

CUNHA, M. I. P. O corpo recluído: controlo e resistência numa prisão feminina. In: ALMEIDA, M. V. de (Org.). Corpo presente: treze reflexóes antropológicas sobre o corpo. Oeiras: Celta, 1996. p. 1-23.

DIUANA, V.; CORREA; M. C. D. V.; VENTURA, M. Mulheres nas prisóes brasileiras: tensóes entre a ordem disciplinar punitiva e as prescriçóes da maternidade. Physis: Revista de Saúde Coletiva. Rio de Janeiro, v. 27, n. 3, p. 727-747, 2017.

FLICK, U. Introdução à pesquisa qualitativa. 3.ed. Porto Alegre: Artmed, 2009.

FOCHI, M. C. S. et al. Vivências de gestantes em situação de prisão. Revista Eletrônica de Enfermagem, Goiânia, v. 19, dez. 2017. Disponível em: <https://www.revistas.ufg.br/fen/article/ view/46647>. Acesso em: 29 jan. 2018.

FREIRE, G.O.B.F. Cárcere e maternidade: o desafio de conciliar custódia e maternidade. 2017. 112 f. Dissertação (Mestrado em Segurança Pública) - Programa de Pós-Graduação em Segurança Pública, Universidade Federal do Pará, Belém, 2017.

HUANG, K.; ATLAS, R.; PARVEZ, F. The significance of breastfeeding to incarcerated pregnant women: an exploratory study. Birth, v.39, n. 2, p. 145-155, 2012. 
LEAL, M. C. et al. Nascer na prisão: gestação e parto atrás das grades no Brasil. Ciência \& Saúde Coletiva. Rio de Janeiro, v. 21, n. 7, p. 2061-2070, 2016.

LIMA, G. M. B. et al. Mulheres no cárcere: significados e práticas cotidianas de enfrentamento com ênfase na resiliência. Saúde em Debate, v. 37, n. 98, p. 446-456, 2013.

LIMA, G. M. B. A vida de mulheres na prisão: legislação, saúde mental e superlotação em João Pessoa-PB. 2013. 124p. Tese (Doutorado em Ciências - Saúde Pública). - Escola Nacional de Saúde Pública Sérgio Arouca, Fundação Oswaldo Cruz, João Pessoa, 2013.

ORMEÑO, G. R.; MAIA, J. M. D; WILliAMS, L. C. A. Crianças com pais ou mães encarcerados: uma revisão de literatura. Revista de Psicologia da Criança e do Adolescente. Lisboa, v. 4, n. 2, 2013.

POEHLMANN, J. Representations of Attachment Relationships in Children of Incarcerated Mothers. Child Development, v.76, n. 3, 679-696, 2005.

POEHLMANN, J. et al. Children's contact with their incarcerated parents: Research findings and recommendations. American Psychologist, v.65, n. 6, p. 575-598, 2010.

POEHLMANN, J.; SCHLAFER, R.J.; MAES, E. Factors associated with young children's opportunities for maintaining family relationships during maternal incarceration. Family Relations, v. 57, n. 3, p. 267-280, 2008.

RAEDER, M. S. Making a better world for children of incarcerated parents. Family Court Review, v. 50, n. 1, p. 23-35, 2012.

SILVA, A. D. Mãelmulher atrás das grades: a realidade imposta pelo cárcere à família monoparental feminina [online]. São Paulo: Editora UNESP/Cultura Acadêmica, 2015, 224p. Disponível em: <http://books.scielo.org>. Acesso em: 10 jun. 2017.

SOARES, B. M.; ILGENFRITZ, I. Prisioneiras: vida e violência atrás das grades. Rio de Janeiro: Garamond, 2002.

SOARES, I. R.; CENCI, C. M. B.; OLIVEIRA, L. R. F. Mães no cárcere: percepção de vínculo com os filhos Mothers de mulheres encarceradas em todo o território nacional. Estudos e Pesquisas em Psicologia. Rio de Janeiro, v. 16, p. 27-45, 2016.

SPINDOLA, L. S. A mulher encarcerada no sistema penal brasileiro: a busca de soluçôes para as especificidades do gênero feminino no tocante à maternidade. Brasília: Instituto Brasiliense de Direito Público, 2016. 29f.

STELLA, C. O impacto do encarceramento materno no desenvolvimento psicossocial dos filhos. Educare. Revista de Educação, v. 4, n. 8, p. 99-111, 2009.

VALENTE, D. L.; HADLER, O. H.; COSTA, L. B. Por uma klinica cartográfica: a experiência da maternidade em mulheres em privação de liberdade. Revista de Psicologia da IMED, v. 4, n. 2, p. 681-691, 2012. 
VARELLA, D. As prisioneiras. São Paulo: Companhia das Letras, 2017.

WACQUANT, L. A aberração carcerária à moda francesa. Dados, v. 47, n. 2, p. 215-232, 2004.

\section{Notas}

${ }^{1}$ Este manuscrito é parte da dissertação apresentada ao Curso de Mestrado Profissional em Saúde Materno-Infantil, Universidade Franciscana (UFN), 2018.

${ }^{2}$ N. M. P. Flores e L. N. Smeha participaram igualmente da concepçấo do projeto de pesquisa, coleta e análise de dados, redação e formatação do artigo. 


\section{Abstract}

Arrested mothers, helpless children: motherhood and interpersonal relationships in prison

This study aimed to elucidate the repercussion of the imprisonment of women in the context of maternity and interpersonal relations established before and during the fulfillment of the sentence. This is an exploratory and cross-sectional research with a qualitative design, with 15 participants arrested in closed regime. A total of 13 semi-structured interviews and 3 focus groups were conducted between April and July 2017. The data were submitted to a content analysis. It was concluded that the precariousness of interpersonal relations, established during the fulfillment of the sentence, influence the possibilities of exercising maternity in the prison context. Therefore, investments are needed to mediate the prison environment, making it more conducive to interpersonal relationships among prisoners, which may provide a less hostile environment for the reception of visitors, with a view to strengthening ties with children and relatives.

Keywords: prisons; mother-child relationship; interpersonal relations; maternal and child health. 